\title{
Persistent Activity of a Single Late-Season Treatment with Ivermectin against Gastrointestinal Trichostrongyles and Lungworm in Young Calves
}

\author{
By P. Steffan and P. Nansen \\ Department of Veterinary Microbiology, \\ Royal Veterinary and Agricultural University, Denmark.
}

\begin{abstract}
Steffan, P. and P. Nansen: Persistent activity of a single late-season treatment with ivermectin against gastrointestinal trichostrongyles and lungworm in young calves. Acta vet. scand. 1990, 31, 237-242. - The present study was designed to assess the persistent efficacy of ivermectin against gastrointestinal trichostrongyles and lungworm (Dictyocaulus viviparus) when given late in the season to young calves naturally exposed to infection on permanent pasture. The results suggest that ivermectin prevents the re-establishment of Ostertagia spp. for 2 to 3 weeks, but Cooperia spp. for only 1 to 2 weeks. Re-establishment of lungworm is prevented for a period of at least 3 weeks. The results are discussed in the light of recent studies on the ivermectin effects on experimental or early-season natural infections.
\end{abstract}

Ostertagia spp; Cooperia spp; Dictyocaulus viviparus; tactical treatment.

\section{Introduction}

Much of the available literature on ivermectin focuses on its persistent suppressive effect on nematodes. Experimental documentation of this effect is mainly based on studies where animals have been artificially infected at different time intervals after the ivermectin treatment (Barth 1983, Armour et al. 1985), or where animals after treatment at the beginning of the grazing season have been transferred to naturally infected pasture (e.g. Armour et al. 1987, Herd et al. 1987, Jacobs et al. 1987). In contrast, very little attention has been paid to the persistent activity of ivermectin when administered to cattle with already established parasitic infections and under continuous high larval challenge, as e.g. late in the grazing season.

The purpose of this experiment was to assess the persistent, suppressive effect of ivermectin on faecal excretion of eggs of gastrointestinal trichostrongyles and of larvae of the lungworm Dictyocaulus viviparus, when the drug was administered late in the season to young calves on permanent pasture. For comparison, treatment with a short-acting anthelmintic, levamisole, was included in the experiment.

\section{Materials and methods Experimental field}

The experiment was carried out from August 1 st to October 2nd in North Zealand on a research station belonging to the National Institute of Animal Science. A permanent pasture which had been grazed by young cattle earlier in the season and during the preceding years, was used. 
Experimental animals and grazing scheme Twenty-seven first-season Black-Pied Danish heifer calves, aged 9-12 months, were used. They had been grazing on another permanent pasture since May the same year. As judged from faecal egg counts, they had been exposed to moderate herbage infectivity with trichostrongyles. It was informed that no anthelmintics had been administered.

During the period from August 1st to October 2 nd all animals were grazed together in one herd. This ensured that all calves were exposed to the same level of herbage infectivity throughout the experimental period.

\section{Anthelmintic treatment}

The calves were allocated into 3 comparable groups and treated as shown in Table 1.

Table 1. Experimental groups of calves and anthelmintic treatments.

\begin{tabular}{lcll}
\hline Group & $\begin{array}{c}\text { No. of } \\
\text { animals }\end{array}$ & Treatment & $\begin{array}{l}\text { Date of } \\
\text { treatment }\end{array}$ \\
\hline 1 & 9 & Control & - \\
2 & 9 & Levamisole & $\begin{array}{l}\text { August 7th } \\
\text { August 7th }\end{array}$ \\
\hline
\end{tabular}

The calves in group 1 served as untreated controls. Levamisole was administered to group 2 by subcutaneous injection in a hydrogen chloride formulation (Lundbeck Ltd., Denmark) at a dose rate of $7.5 \mathrm{mg}$ per $\mathrm{kg}$ bodyweight. Ivermectin (MSD AGVET, Ltd.) was given to group 3 by subcutaneous injection at a dose rate of $0.2 \mathrm{mg}$ per $\mathrm{kg}$ body weight.

\section{Experimental parameters}

Faecal samples were collected at weekly intervals, and nematode eggs were determined by a modified McMaster technique (Henriksen \& Korsholm 1984). At the same time, faecal cultures to obtain third-stage larvae were carried out according to the technique of Henriksen \& Korsholm (1983). Larval differentiation was performed according to the description of Corticelli \& Lai (1983). In each sample differentiation was based on microscopical examination of more than 50 larvae. Where there were less than 50 individuals in a sample, all were examined. The larval differentiation formed the basis for presentation of the faecal egg counts at genus level. This seemed justifiable since it was shown in a recent study by Steffan et al. (1989) that the proportions of eggs developing to third-stage larvae recoverable by the method used, were similar for $O$. ostertagi and C.oncophora. Analysis for Dictyocaulus viviparus larvae was performed by baermannization of fresh faecal samples (Henriksen 1965).

Grass samples for the determination of gastrointestinal trichostrongyle larvae and lungworm were collected following a zig-zag course across the pasture and, stopping at every 10 steps, small plucks of grass were picked up to complete a bulk sample of approximately $500 \mathrm{~g}$ per plot. Infective larvae were recovered by the technique described by Jørgensen (1975) and subsequently counted, differentiated, and expressed as numbers per $\mathrm{kg}$ of dried grass.

\section{Results}

Egg counts

Faecal egg counts of the genera Ostertagia and Cooperia are shown in Figs. 1 and 2, respectively. A few Nematodirus spp. eggs were noticed in the faeces of untreated calves (group 1) in weeks 2 and 3.

Ostertagia spp. egg counts (Fig. 1) remained fairly constant in untreated calves (group 1), apart from the last 2 weeks where a certain rise was observed. In the levamisole treated group (group 2) the egg counts were almost zero 1 and 2 weeks after the treatment, differing significantly from those 


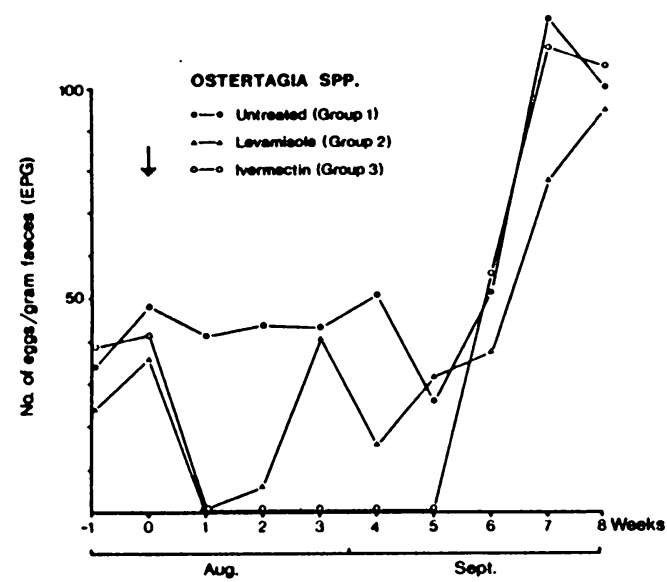

Figure 1. Mean faecal egg counts of Ostertagia $s p p$. following anthelmintic treatment.

of group 1 ( $p<0.001)$. Subsequently eggs reappeared in higher numbers, and levels approached those of the untreated group. Ivermectin completely suppressed egg excretion during the first 5 weeks after treatment (group 3). From week 6, eggs reappeared in numbers comparable to those of the untreated calves.

Cooperia spp. egg counts (Fig. 2) in the untreated calves (group 1) were roughly comparable to counts of Ostertagia in the same group. Levamisole (group 2) seemed to

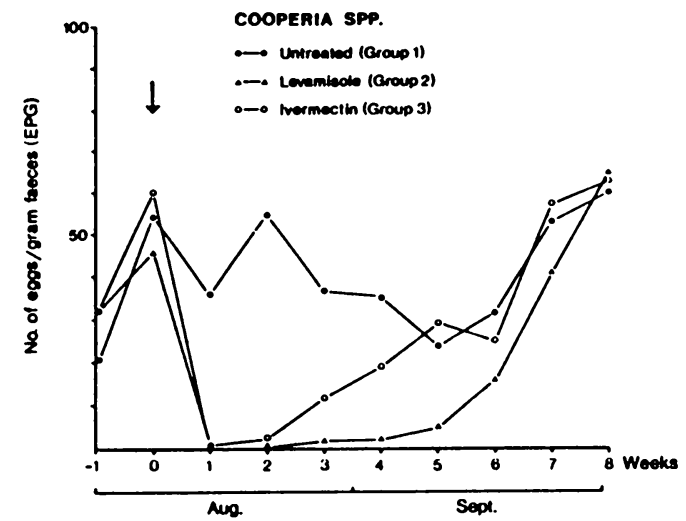

Figure 2. Mean faecal egg counts of Cooperia $s p p$. following anthelmintic treatment. reduce numbers of eggs of Cooperia much more effectively than it reduced those of Ostertagia (Fig. 1), in that egg counts remained significantly lowered $(p<0.05)$ during the first 4 weeks after the treatment. Treatment with ivermectin (group 3) reduced egg counts to almost zero for the first 2 weeks, but already in week 3 , counts rose and became statistically indistinguishable from those of the untreated calves.

Excretion of lungworm larvae (Fig. 3).

The excretion of Dictyocaulus viviparus larvae is shown in Fig. 3. In week 4, lungworm larvae were recorded in 8 out of the 9 calves of each of groups 1 and 2, and peak levels were observed in week 6 . In contrast, calves treated with ivermectin (group 3) did not pass larvae in faeces until week 7 to 8 where only very few larvae were excreted by 2 calves.

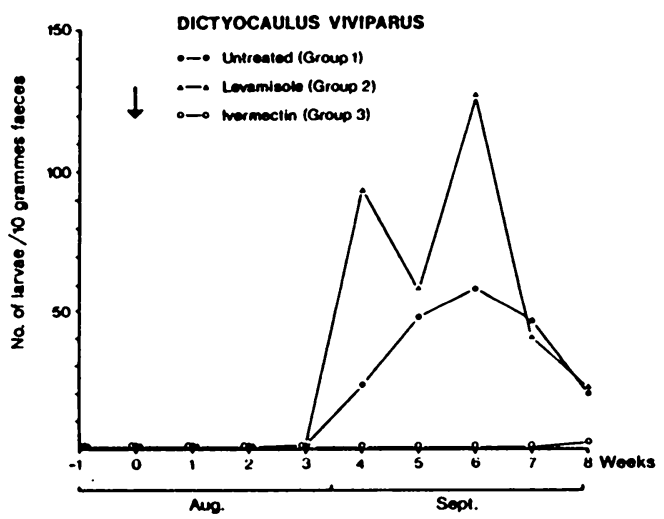

Figure 3. Mean faecal larval counts of Dictyocaulus viviparus following anthelmintic treatment.

\section{Herbage infectivity}

Numbers of gastrointestinal trichostrongyle larvae per $\mathrm{kg}$ dry herbage varied between 200 and 1,700 in August and between 1,900 and 8,000 in September. Ostertagia spp. made the major contribution. A few Nematodirus spp. larvae were observable on 1 
occasion. Lungworm larvae were not detectable in herbage until week 5 after the treatment date, despite the fact that the calves must have been exposed to the parasite several weeks earlier (as evidenced from the faecal larval excretion pattern). In fact, the lungworm larvae recoverable in the herbage from week 5 and onwards may have been a direct result of the larval deposition observed.

\section{Clinical findings}

No overt clinical signs of gastrointestinal parasitism were noticed. Coughing and elevated respiratory rates were observed in September in some calves of the untreated group 1 and the levamisole treated group 2, but the lungworm infection did not reach any clinically critical stage.

\section{Discussion}

In this study on continuously exposed calves under natural grazing conditions, treatment with ivermectin eliminated Ostertagia spp. egg excretion for a period of 5 weeks after treatment. In view of the fact that the prepatent period of gastrointestinal trichostrongyles is approx. 3 weeks, ivermectin treatment may have prevented the re-establishment of Ostertagia spp. for a period of 2 to 3 weeks. This is in line with Barth (1983) and Armour et al. (1985) who, on the basis of experimental infections after treatment, found a residual activity of ivermectin against gastrointestinal nematodes of at least 2 weeks. The consonance between these observations may be explained by findings of Bogan \& McKellar (1988) who showed that the concentration of ivermectin at the level of abomasal fluids are not modified by established parasitic infections.

The efficacy of ivermectin against Cooperia spp. appeared to be lower than that against Ostertagia spp. Thus, egg excretion of $\mathrm{Co}$ - operia spp. was only significantly diminished for 2 weeks after the ivermectin treatment. This observation is in accordance with studies by Borgsteede \& Hendriks (1986) who showed that in mixed trichostrongyle infections, only larvae of Cooperia $s p p$. could be cultured from faeces soon after treatment with ivermectin. Bogan et al. (1988) have suggested that individuals of Cooperia spp., which are located proximally in the small intestine and paralysed by the effects of ivermectin, may have sufficient time to re-establish before they are carried out from the small intestine. This would not be the case for Ostertagia spp.

The effects of levamisole on the gastrointestinal trichostrongyle egg excretion was as expected; yet the effect on Cooperia spp. was surprisingly high. Levamisole has shown a high efficacy against both adult and immature stages of Dictyocaulus viviparus (Brome \& Lewis 1974, Oakley 1981, Pouplard et al. 1986). It is then reasonable to suggest that in this experiment larvae producing mature worms were acquired from the infected experimental pasture and not from resumption of eventually inhibited fifth-stage larvae (Taylor \& Michel 1952) acquired prior to the experiment.

A highly persistent anthelmintic activity of ivermectin against lungworm was recorded in the present experiments. Despite the fact that all groups of calves were exposed to the same herbage infectivity on the experimental pasture, the ivermectin treated calves did not pass larvae in their faeces until 7 weeks after treatment, as compared with the controls where 8 out of 9 animals excreted larvae at week 4 . This suggests a persistent activity of at least 3 weeks, which is in line with Armour et al. (1987). Jacobs et al. (1984) showed that ivermectin very quickly reaches high levels in lung tissue, and this 
may confer the exceptionally high efficacy against lungworm.

The results of the present experiments strongly emphasize the potentials of ivermectin; not only when used in early-season strategic programmes, but perhaps also in late-season tactical treatments. The feasibility of this latter form of control should be explored further.

\section{References}

Armour J, Bairden K, Batty AF, Davidson CC, Ross DB: Persistent anthelminthic activity of ivermectin in cattle. Vet. Rec. 1985, 116, 151153.

Armour J, Bairden K, Pirie HM, Ryan WG: Control of parasitic bronchitis and gastroenteritis in grazing cattle by strategic prophylaxis with ivermectin. Vet. Rec. 1987, 121, 5-8.

Barth D: Persistent anthelmintic effect of ivermectin in cattle. Vet. Rec. 1983, 113, 300.

Bogan J, McKellar QA: The pharmacodynamics of ivermectin in sheep and cattle. J. vet. Pharmacol. Therap. 1988, 11, 260-268.

Bogan J, McKellar QA, Mitchell ES, Scott EW: Efficacy of ivermectin against Cooperia curticei infection in sheep. Amer. J. vet. Res. 1988, 49, 99-100.

Borgsteede FMH, Hendriks J: The residual effect of treatment with ivermectin after experimental reinfection with nematodes in calves. Vet. Quart. 1986, 8, 98-104.

Broome AWJ, Lewis JA: Activity of levamisole against development stages of Dictyocaulus viviparus in experimentally infected calves. Vet. Rec. 1974, 94, 563-566.

Corticelli B, Lai M: Studies on the technique of culture of infective larvae of gastrointestinal strongyles of cattle. Acta Med. Vet. 1963, 9 , 347-357.

Henriksen, SvAa: An improved technique for the examination of faeces for larvae of lungworms. Nord. Vet.-Med. 1965, 17, 446-454.

Henriksen SvAa, Korsholm H: A method for culture and recovery of gastrointestinal strongyle larvae. Nord. Vet.-Med. 1983, 35, 429-430.
Henriksen SvAa, Korsholm H: Parasitologiske undersøgelser af fæcesprøver. Konstruktion og anvendelse af et enkelt opbygget tællekammer. (Parasitological examination of faeces samples. Construction and application of a aimple counting chamber). Dansk Vet.-tidsskr. 1984, 67, 1193-1196.

Herd RP, Reynemeyer CR, Heider LE: Control of gastrointestinal nematodes in dairy heifers by two strategic treatments with ivermectin. Vet. Rec. 1987, 120, 406-409.

Jacobs TA, Buhs RP, Carlin JR, Chiu SHL, Miwa $G$, Rosegay $A$ : The metabolism and tissue residue profiles of ivermectin. In: Leaning WHD, ed., Recent Developments in Control of Animal Parasites. Proc. MSD-AGVET Symp., Perth, Australia, 1984.

Jacobs DE, Fox MT, Ryan WG: Early season parasitic gastroenteritis in calves and its prevention with ivermectin. Vet. Rec. 1987, 120 , 29-31.

Jorgensen RJ: Isolation of infective Dictyocaulus larvae from herbage. Vet. Parasitol. 1975, 1 , 61-67.

Oakley GA: Efficacy of levamisole against inhibited Dictyocaulus viviparus infection in cattle. Res. Vet. Sci. 1981, 30, 127-128.

Pouplard L, Lekeux P, Detry M: Efficacy of ivermectin and levamisole against immature Dictyocaulus viviparus in cattle. Vet. Rec. 1986, 118, 557-559.

Steffan P, Henriksen SvAa, Nansen P: Faecal larval cultivation of bovine trichostrongyles: $A$ comparison of two methods and two additives. Vet. Parasitol. 1989, 31, 269-273.

Taylor EL, Michel JF: Inhibited development of Dictyocaulus larvae in the lungs of cattle and sheep. Nature, UK, 1952, 169; 753.

\section{Sammendrag}

Persisterende effekt af en enkelt sensommer behandling med ivermectin mod gastrointestinale trichostrongylider og lungeorm $i$ unge kalve. Nærværende undersøgelse var tilrettelagt for at vurdere effekten af ivermectin over for gastrointestinale trichostrongylider og over for lungeorm (Dictyocaulus viviparus). Ivermectin blev givet 
som enkeltbehandling sidst i græsningssæsonen til kalve, som opholdt sig på naturligt inficeret, permanent græsgang. Resultaterne syntes at vise, at ivermectin hindrede etablering af Ostertagia spp. i 2-3 uger, men Cooperia spp. i kun 1-2 uger. Behandlingen syntes at forhindre etablering af lunge- orm i en periode på mindst 3 uger. Resultaterne sammenholdes med nyere undersøgelser over ivermectin's effekt over for eksperimentelle infektioner eller naturlige infektioner tidligt i græsningssæsonen.

(Received June 6, 1989; accepted September 5, 1989).

Reprints may be requested from: P. Nansen, Royal Veterinary and Agricultural University, Dep. of Vet. Microbiology, Laboratory of Parasitology,

13, Bülowsvej, DK-1870 Frederiksberg C, Denmark. 